\title{
Cashless payment and economic growth
}

\author{
Hock-Han Tee and Hway-Boon Ong*
}

\author{
* Correspondence: hbong@mmu. \\ edu.my \\ Economics Unit, Faculty of \\ Management, Multimedia \\ University, Persiaran Multimedia, \\ 63100 Cyberjaya, Malaysia
}

\begin{abstract}
Background: This study examines the effect of adopting cashless payment in five European Union (EU) countries, namely, Austria, Belgium, France, Germany, and Portugal, for the period of 2000-2012.

Methods: The within and between effect of adopting cheque payment, telegraphic transfer, card payment and electronic money on these EU's economy are examined by applying the Pedroni residual cointergration and Panel Vector Error Correction Model (VECM).

Results: There is short run causality running from cheque payment to telegraphic transfer and card payment, as well as causality running telegraphic transfer to card payment. In the long run, there is significant effect of adopting cashless payment on the economy of the five EU countries.

Conclusions: The adoption of one type of cashless payment will affect another type of cashless payment in the short run. The impact of adopting cashless payment on economic growth can only be significantly observed in the long run. Hence, any policy that promotes cashless payment will not affect the economy immediately.
\end{abstract}

\section{Background}

The advancement of information technology has facilitated innovation in electronic payment where goods and services are traded without the use of physical cash. A cashless payment eliminates the usage of money as a medium of exchange for goods and services by allowing electronic transfer payments or non-electronic payment via cheques. Adopting cashless payment has numerous advantages. Unlike traditional cash transaction, cashless payments discourage robbery and other cash related crimes (Armey et al. 2014). When people opt for other alternative modes of payment, they tend to hold less physical cash when they shop. Thus, it eliminates the incentive for robbers to commit cash related crimes. As for vendors, the ease of transaction through various payment modes will increase their revenue, improve operational efficiency and lower operating cost (Alliance 2003). Cashless payments were also regarded as hygienic for food vendors (Paul and Friday 2012).

Electronic card payments will have a meaningful impact on the world economy. According to Moody's Analytics published by Visa Inc., ${ }^{1}$ greater usage of electronic card payment products added $\$ 983$ billion in real U.S. dollars to the GDP of 56 countries they studied from 2008 to 2012. Card payment has raised consumption by an average of $0.7 \%$ across the 56 countries. The real global GDP grew by an average of $1.8 \%$ during that time

(c) 2016 Tee and Ong. Open Access This article is distributed under the terms of the Creative Commons Attribution 4.0 International License (http://creativecommons.org/licenses/by/4.0/), which permits unrestricted use, distribution, and reproduction in any medium, provided you give appropriate credit to the original author(s) and the source, provide a link to the Creative Commons license, and indicate if changes were made. 
period (Zandi et al. 2013). At present, the electronic payment have substantially replaced payment by cheques but it has not led to a cashless society (Liao and Handa 2010).

The EU had recently established the Single Euro Payment Area (SEPA) that integrated all Euro electronic payment systems. SEPA eliminates technical, legal, and geographic barriers for electronic payments and allows domestic and cross-border euro payment. The European Payment Council, a self-regulatory body, had also developed a SEPA payment scheme for credit transfer and direct debit (European Central Bank 2014). The implementation of SEPA enables all forms of electronic payments possible in the Euro area. The economic opportunities of SEPA can be analysed by examining how cashless payment facilitates economic activities and produce positive gross domestic product (GDP) growth in the Euro area.

\section{Cashless payment}

A cashless transaction refers to an economic setting whereby goods and services are transacted without cash (Paul and Friday 2012), either through electronic transfer or cheque payment. The effect of cashless payment on an economy can be analysed by the Diffusion of Innovation Theory (DOI). The concept was first introduced by Roger in 1962 where he explained how innovation is diffused to members of a social system over time (Rogers, 1995). According to DOI, the adoption of a new idea or innovations is caused by interaction between individuals through interpersonal networks. In this context, diffusion is the spread of cashless payment where consumers seek improved and convenient transaction, while businesses seek new profit opportunities. The diffusion of cashless payment will result in the adoption of cashless transactions within the society or community, subject to the types of innovation adopters ${ }^{2}$ and innovation-decision process. ${ }^{3}$ Since the consequences of diffusion in cashless payment depend on how quickly the society is willing to adopt cashless payment through different stages of innovation processes, the consequences of the adoption of cashless payment differs in different society.

Earlier study by Fox (1986) stated that during the 1960 and 1970's, the adoption of electronic fund transfer would serve as a substitute for cheques and cash as the primary mode of payment in the United State. Today, the use of electronic payment has continued to increase due to its convenience, safety and swift mode of payment. Oyewole et al. (2013) discovered that adopting electronic payment will positively affect economic growth and trade in Nigeria. Hasan et al. (2012) examined the fundamental relationship between the adoption of electronic retail payment and overall economic growth across 27 European countries from the period 1995-2009. They discovered that migration to an effective electronic retail payment would stimulate the overall economic growth, consumption, and trade. However, the impact of credit and debit card payment, fund transfers and cheques payment on the economy are relatively low.

Zandi et al. (2013) studied whether the long-term shift to credit and debit cards stimulates economic growth of 56 countries worldwide. They discovered that electronic card payments can increase efficiency and boost consumption of the economy. Moreover, the adoption of electronic transaction is essential for transparency, accountability and reduction of cash related fraud, the fundamental elements of economic growth and development (Mieseigha and Ogbodo 2013). 
Electronic payments will replace cheque payments extensively but cash-based payment will persist to a substantial extent (Liao and Handa 2010). Although technological advancement has enabled improvement and innovation in electronic payment system (Oyewole et al. 2013), from the basic ATM card transaction to online credit transfer, direct debit, card payments and cheques, security related issues, non-IT savvy users and phishing emails are some of the shortcomings of the adoption of cashless payments. The loss of money and the compromise of private information weaken the confidence of consumers to make payment electronically. Park (2012) studies more than 70 countries around the world, from the less developed Bangladesh to the developed United States for the period 2002-2004. They found that corruption in the banking sector could distort economic growth because the allocation of fund for private investment will be biased. Consequently, private investment will take its toll on economic growth.

Moreover, Ezuwore-Obodoekwe et al. (2014) discovered that as Nigerians moved from a cash-base to a cashless society, its Central Bank would lose its autonomy on monetary policy. When the central bank loose its ability to control money supply, the increase in the velocity of money will produce an exponential increase in prices, causing the economy to experience inflation (Al-laham and $\mathrm{Al}$ tarawneh 2009).

There is no conclusive evidence on how the adoption of cashless payment might affect an economy. Cashless payment might have a positive impact on economic activities (Hasan et al. 2012; Oyewole et al. 2013; Zandi et al. 2013) but it also provide an opportunity for corruption (Park 2012), caused bankruptcy among youth (Noordin et al. 2012) and reduced policy control of the monetary system (Al-laham and Al-tarawneh 2009; Ezuwore-Obodoekwe et al. 2014).

The motivation of this paper is to study the economic opportunities of SEPA in facilitating economic activities in the Euro area. This study examines the impact of adoption of various cashless payments, namely, card, telegraphic transfers, electronic money and cheques on Austria, Belgium, France, Germany and Portugal in two folds. Firstly, this study examines within and between effects of adopting cashless payments on the selected EU's economy. Secondly, this study determines the short and long run causality of each cashless payment modes on EU's economy.

In the next section of this paper, a review on cashless transactions is presented, to be followed by a discussion on methodology and findings. Finally, some discussion and concluding remarks are presented.

\section{Methods}

This study examines the dynamic causal relationship of adopting cashless payment on five EU economies, namely, Austria, Belgium, France, Germany, and Portugal. Telegraphic transfer, card payment, electronic money, and cheque payment are the proxies for cashless payment. The real gross domestic product is computed by dividing gross domestic product (GDP) by its consumer price index (CPI). The annual GDP and CPI of Austria, Belgium, France, Germany, and Portugal 2004 to 2012 are obtained from International Monetary Fund's International Financial Statistics. The real GDP has been used as a proxy for economic growth (Apergis and Payne 
2010; Slesman et al. 2015; Wang et al. 2016), economic activities (McCoskey and Selden 1998; Cevik et al. 2016) and productivity (Conti 2014). Thus, in this study, real GDP is employed as a proxy for economic growth.

Data for telegraphic transfer, card payment, electronic money and cheques payment for the period 2004 to 2013 are obtained from the European Central Bank's Statistical Data Warehouse. Telegraphic transfer, also known as electronic fund transfer, is payment made through real-time request or offline. ${ }^{4}$ Telegraphic transfer is computed by summing up the credit and transfers of respective countries. Payment transaction performed with a debit, ${ }^{5}$ credit $^{6}$ or charge card $^{7}$ is classified as card payment. Electronic money is the total outstanding amounts of stored monetary value on an electronic devise (server or card), at the end of the period.

The underlying empirical equation is specified as follows:

$$
R G D P_{i t}=\beta_{1 i}+\beta_{2 i} T T_{i t}+\beta_{3 i} C P_{i t}+\beta_{4 i} E M_{i t}+\beta_{5 i} C h e_{i t}+e_{i t}
$$

whereby $\mathrm{RGDP}_{\mathrm{it}}$ is the real gross domestic product for country $\mathrm{i}$ at time $\mathrm{t}, \mathrm{TT}_{\mathrm{it}}$ is the total value of telegraphic transfer from country $i$ at time $t, \mathrm{CP}_{\text {it }}$ is the total value of card payment transaction in country $i$ at time $t, E M_{i t}$ is the total value of purchases done through electronic money in country $i$ at time $t$, and $C e_{i t}$ is the total value of cheques issued for the purchase of goods and services in country $i$ at time $t$.

\section{Panel unit root}

In order to avoid spurious regression of non-stationary series at level, all series are tested for unit root by employing the Im, Pesaran and Shin (IPS) and the ADF-Fisher chi-square panel unit root tests. The Im, Pesaran, \& Shin (IPS) panel unit root test extended the Levin et al. (2002) test by allowing for heterogeneity of the $\gamma$ coefficient. The IPS test allows $\gamma$ varying across all i using the following model:

$$
\Delta y_{i t}=\lambda_{i}+\gamma_{i} y_{i t-1}+\sum_{j=1}^{k} \beta_{j} \Delta y_{i t-j}+\phi_{i} t+\theta_{t}+\varepsilon_{i t}
$$

Equation 2 is the IPS test based on the Augmented Dickey Fuller (ADF) statistics averaged across groups. The null hypothesis is tested for $H_{0}: \gamma_{i}=0$ for all i against the alternative hypothesis of $H_{1}: \gamma_{i}<0$ for at least one i. The null hypothesis indicates a unit root problem and the alternative hypothesis implies that some of the series in the panel data are stationary.

Maddala and Wu (1999) proposed the Fisher-type or ADF-Fisher unit root test as follows:

$$
\tau=-2 \sum_{i=0}^{n} \ln \rho_{i}
$$

where the $p$-values is the independent ADF unit root tests for each cross-section i, based on an asymptotic chi-square distributed with 2 n degrees of freedom. 


\section{Panel cointegration}

The panel cointegration tests developed by Pedroni (1999) is applied to test the existence of the long run equilibrium relationship among the five EU economies. From Eq. (1), for example, the estimated residual is as follows:

$$
\begin{aligned}
& \hat{e}_{i t}=R G D P_{i t}-\hat{\beta}_{1 i}-\hat{\beta}_{2 i} T T_{i t}-\hat{\beta}_{3 i} C P_{i t}-\hat{\beta}_{4 i} E M_{i t}-\hat{\beta}_{5 i} C h e_{i t} \\
& \Delta \hat{e}_{i t}=\rho \hat{\mu}_{i t-1}+\sum_{k=1}^{K_{i}} \gamma_{i k} \Delta \hat{\mu}_{i t-k}+v_{i t}
\end{aligned}
$$

where $\gamma_{i k}$ and $K_{i}$ are allowed to vary across units. The null hypothesis of no cointegration is tested for $H_{0}: \rho_{i}=1$ for all $\mathrm{i}$ against the alternative hypothesis of cointegration is tested for $H_{1}: \rho_{i}<0$ for all i. Pedroni's panel cointegration employs seven tests for within-dimension and between-dimension relationship.

When the cointegration relationship is determined, the cointegrating parameters is estimated by group-mean panel fully modified ordinary least squares (FMOLS), since the FMOLS method is corrected for endogeneity and serial correlation in cointegrating regression (Inagaki 2010; Liddle 2012). The panel cointegration analysis requires the panels with large number of countries $(\mathrm{N})$ and small length of the time series $(\mathrm{T})$, or $\mathrm{N}<\mathrm{T}$. This method is not applicable if there is no evidence of cointegrating relationship across units and when panels have large $\mathrm{N}$ and large $\mathrm{T}$.

The lag of the residuals of the group-mean panel FMOLS are retained and incorporated in the first difference of Eq. (1) to capture the long-run relationship of cashless payment on EU economies. The panel VECM is modelled as follow:

$$
\begin{aligned}
& \Delta R G D P_{i t}=\delta_{i}+\sum_{\rho-1}^{k} \beta_{2 i \rho} \Delta T T_{i t-\rho}+\sum_{\rho-1}^{k} \beta_{3 i \rho} \Delta C P_{i t-p} \\
& +\sum_{\rho-1}^{k} \beta_{4 i \rho} \Delta E M_{i t-\rho}+\sum_{\rho-1}^{k} \beta_{5 i \rho} \Delta C h e_{i t-\rho}+\theta_{t} \hat{\varepsilon}_{i t-1}+u_{i t}
\end{aligned}
$$

where $\beta_{i}$ are the parameters to be estimated, $\mathrm{k}$ is the optimum lag length, $\hat{\varepsilon}_{i t-1}$ is the lag of the residual from the group-mean panel FMOLS. The short run Granger causality is tested with a Wald test of the chi-square statistics by alternately imposing $\beta_{2 i p}$, $\beta_{3 i p}$ and $\beta_{4 i p}$ to zero. The long run causality is checked by the statistical significance of the $t$-test on the parameter $\theta_{t}$ of the error correction term.

\section{Results and discussion}

The IPS and ADF-Fisher unit root tests are used to determine the stationary of each variable. Both IPS and ADF-Fisher shows that all variable are stationary in first deference. Refer to Table 1 for details.

Since all variable are stationary after first differencing, the next test to be conducted is the Kao (1999) and Pedroni (1999) cointergration tests. Both tests are carried out to determine the cointergration relationship between the adoption of cashless payment and economic growth. Based on Kao's cointergration test, the critical value of tstatistics of -1.4545 rejects the null hypothesis of no cointegration at $10 \%$ level of significance. By rejecting the null hypothesis, the test statistics indicates that there is 
Table 1 Panel unit root

\begin{tabular}{|c|c|c|c|c|c|c|c|c|}
\hline & Im, Pesaran & and Shin & & & ADF - Fish & & & \\
\hline & At Level & & 1st Difference & & At Level & & 1st Differenc & \\
\hline & Intercept & $\begin{array}{l}\text { Intercept } \\
\text { and trend }\end{array}$ & Intercept & $\begin{array}{l}\text { Intercept } \\
\text { and trend }\end{array}$ & Intercept & $\begin{array}{l}\text { Intercept } \\
\text { and trend }\end{array}$ & Intercept & $\begin{array}{l}\text { Intercept } \\
\text { and trend }\end{array}$ \\
\hline RGDP & $0.8223(0)$ & $0.9968(1)$ & $-2.7874(1)^{* * *}$ & $-1.6815(1)^{* *}$ & $5.1035(0)$ & $6.3962(1)$ & $24.089(1)^{* * *}$ & $17.3228(1)^{*}$ \\
\hline$\pi$ & $-0.4180(1)$ & $0.0685(1)$ & $-4.0194(0)^{* * *}$ & $-2.3304(0)^{* * *}$ & 10.763(1) & $8.4698(1)$ & $33.531(0)^{* * *}$ & $22.5708(0)^{* *}$ \\
\hline$C P$ & $4.4422(0)$ & $0.6077(1)$ & $-2.9560(1)^{* * *}$ & $-3.1328(1)^{* * *}$ & $0.5009(0)$ & $6.2787(1)$ & $25.285(1)^{* * *}$ & $27.008(1)^{* * *}$ \\
\hline EM & $0.5249(1)$ & $0.9926(1)$ & $-2.3268(1)^{* *}$ & $-3.8387(1)^{* * *}$ & $13.852(1)$ & $9.0398(1)$ & $28.255(1)^{* * *}$ & $32.545(1)^{* * *}$ \\
\hline Che & $1.5429(0)$ & $0.5241(1)$ & $-3.6186(1)^{* * *}$ & $-2.9243(1)^{* * *}$ & $5.1035(0)$ & $6.3962(1)$ & $24.089(1)^{* * *}$ & $17.323(1)^{*}$ \\
\hline
\end{tabular}

All series are panel data for Austria, Belgium, France, Germany, and Portugal. The RGDP is the real gross domestic product, $\Pi$ is the total value of telegraphic transfer, $C P$ is the total value of card payment transaction, EM is the total value of purchases done through electronic money, and Che is the total value of cheques issued for the purchase of goods and services. The *** and ${ }^{* * *}$ denotes rejection of the null hypothesis of no cointegration, at 10,5 and $1 \%$ level respectively. Maximum lag (in parenthesis) is automatically selected based on Schwarz information criterion

cointergration relationship between cashless payments and economic growth in Austria, Belgium, France, Germany, and Portugal.

The Pedroni (1999) seven panel cointergration test statistics provide a more detailed result as compared to those of Kao's test. Among the seven cointergration test statistics, four are based on within-dimension and the other three are based on between dimension. All Pedroni within-dimension null hypothesis test statistics of no cointergration between cashless payment and economic growth are rejected at the $5 \%$ level of significance, except for panel variance and panel rho. All Pedroni's between-dimension test statistics also rejected the null hypothesis of no cointergration between cashless payment and economic growth at the $5 \%$ level of significance, except for the group variance. Refer to Table 2 for details.

Based on panel VECM, there is a long run relationship among all variables at $1 \%$ level of significance, except for card payment. The usage of card payment is not significantly affected by economic growth and usage of all other methods of cashless payment. In the short run, there are unidirectional relationship Granger causality running from cheque payments to telegraphic fund transfer and card payment. At $5 \%$ level of significance, there is also a short run, one-way causal relationship running for telegraphic transfer to card payment. Refer to Table 3 for details.

This study extends Hasan et al. (2012) study by examining how the adoption of cheque payment, telegraphic transfer, card payment and electronic money affect the economics activity of Austria, Belgium, France, Germany, and Portugal, for the period of 2000-2012. The rejection of Pedroni's no within-dimension null hypothesis indicates that the adoption of one cashless payment method in either Austria, Belgium, France, Germany or Portugal, will affect the usage of the same cashless payment method in

Table 2 Pedroni residual cointegration test

\begin{tabular}{lccccccc}
\hline Models & Panel v & $\begin{array}{l}\text { Panel } \\
\text { rho }\end{array}$ & Panel PP & Panel ADF & $\begin{array}{l}\text { Group } \\
\text { rho }\end{array}$ & $\begin{array}{c}\text { Group PP } \\
\text { ADF }\end{array}$ \\
\hline Deterministic intercept & -0.6885 & 0.6995 & $-4.9928^{* * *}$ & $-4.2132^{* * *}$ & 2.2475 & $-3.4070^{* * *}$ & $-1.9160^{* * *}$ \\
$\begin{array}{l}\text { No deterministic intercept and } \\
\text { trend }\end{array}$ & -1.7442 & 1.2988 & $-2.7423^{* * *}$ & $-2.2420^{* *}$ & 1.9034 & $-7.3923^{* * *}$ & $-5.8199^{* * *}$ \\
\hline
\end{tabular}

The *** and ${ }^{* * *}$ denotes rejection of the null hypothesis of no cointegration, at 10,5 and $1 \%$ level respectively. Maximum lag is automatically selected based on Schwarz information criterion 
Table 3 Panel Causality

\begin{tabular}{lllllll}
\hline Dependent variable & $\Delta$ RGDP & $\Delta E M$ & $\Delta T$ Chi-square & $\Delta C P$ & $\Delta$ Che & Ect t-statistics \\
\hline$\triangle R G D P$ & - & 0.1322 & 1.2627 & 0.0865 & 0.4291 & $-3.6028^{* * *}$ \\
$\Delta \mathrm{EM}$ & 0.0044 & - & 0.3094 & 0.0072 & 0.4857 & $-4.0644^{* * *}$ \\
$\Delta \mathrm{TT}$ & 0.1954 & 0.0023 & - & 0.0719 & $47.2984^{* * *}$ & $-3.2676^{* * *}$ \\
$\Delta \mathrm{CP}$ & 0.4662 & 0.0194 & $4.9791^{* *}$ & - & $24.2170^{* * *}$ & -1.6864 \\
$\Delta \mathrm{Che}$ & 1.7262 & 0.0454 & 1.0616 & 0.9946 & - & $-6.6049^{* * *}$ \\
\hline
\end{tabular}

The *** and ${ }^{* * *}$ denotes rejection of the null hypothesis at the 10,5 and $1 \%$ level respectively. Maximum lag is automatically selected based on Schwarz information criterion

another EU country. The rejection of Pedroni's no between-dimension null hypothesis indicates that the usage of either cheque payment, telegraphic transfer, card payment or electronic money, will significantly trigger the usage of another type of cashless payment. Therefore, it is possible for policymakers and bankers to consider innovating and improving the diffusion of one cashless payment at a time to ensure continuous benefits of the adoption of cashless payment system within the EU community.

In the short run, there is a unidirectional causality from cheque payment to telegraphic transfer and card payment, as well as Granger causality from telegraphic transfer to card payment. Online fund transfer and card payment can be considered as substitute to cheque payment. An increased in the cost of using cheques to pay for goods and services, will directly encourage consumers to seek alternative mode of payment, namely, online transfer or card payment. In electronic commerce, the usage of cheque payment will be less appealing as compared to the convenience of online transfers and card payment.

There is also a long run effect of the adoption of cashless payment on economic growth, except for card payment. This long run relationship implies that the consequences of adopting electronic money, telegraphic transfer, and cheques on the economy of Austria, Belgium, France, Germany and Portugal, can only be significantly observed in the long run. Although these EU countries are developed nation, the effect of increased usage of cashless payment takes time to diffuse and cannot be recognised immediately.

\section{Conclusion}

This paper limits the study of the adoption of cashless payment to card payment, cheques, telegraphic transfer, and electronic money on five EU countries. It is true that trust drives online lending but not electronic payments. The vast development of cashless payment is fueled by the evolution in information technology and innovation in mobile devices. In the near future, technology such as radio frequency identification (RFID) and near field communication (NFC) will dominate the innovation in cashless payment. In 2014, Lollapalooza has launched Lolla Cashless, a cashless payment system through a wristband. The wristband is embedded with a RFID chip and consumer can purchase food and beverages by tapping the wristband on a technology-enable pad. In addition, Apple has also rolled out a new technology called "Apple Pay" in 2014. The Apple Pay is compatible with iPhone 6 and iPhone six Plus, and it is equipped with NFC and Touch ID sensor.

The transformation of the current payment method to a total cashless one may not be possible in the near future, but continuous innovation in technologically aided 
payment system will certainly expand the society's accessibility to cashless payment. Although the adoption of one type of cashless payment will affect another type of cashless payment in the short run, the consequences of adopting cashless payment on economic growth can only be significantly observed in the long run. Hence, any policy that promotes cashless payment will not affect the economy immediately.

\section{Endnotes}

${ }^{1}$ Visa Inc. is an American based credit card service provider that facilitates electronic funds transfers worldwide.

${ }^{2}$ The five types of innovation adopters are innovators, early adopters, early majority, late majority of skeptical adopters, and the laggards whom are conservative.

${ }^{3}$ The five typical stages of innovation decision process of cashless payment are knowledge of the existence of cashless payment, persuasion of a favourable attitude towards cashless payment, decision to adopt cashless payment, implementation of cashless payments and confirmation of the adoption of cashless payment based on positive outcomes.

${ }^{4}$ Offline telegraphic transfers are banks' standing instructions and remittances from customers.

${ }^{5} \mathrm{~A}$ debit card payment allows cardholders to make payment by debiting their bank accounts electronically.

${ }^{6} \mathrm{~A}$ credit card payment allows cardholder to pay for goods and services based on the cardholder's promise to pay for them.

${ }^{7}$ Charge card payments are payments done via American Express or Diners Club.

Competing interests

The authors declare that they have no competing interests

Authors' contributions

Hock-Han Tee carried out data collection and participated in the panel data analysis. Hway-Boon Ong also participated in the panel data analysis and and drafted the manuscript. Both authors have read and approved the final manuscript.

Received: 4 September 2015 Accepted: 30 March 2016

Published online: 07 April 2016

References

Al-laham M, Al-tarawneh H (2009) Development of electronic money and its impact on the central bank role and monetary policy

Alliance SC (2003) Contactless payment and the retail point of sale : applications, technologies and transaction models

Apergis N, Payne JE (2010) Energy consumption and growth in South America: evidence from a panel error correction model. Energy Econ 32:1421-1426. doi:10.1016/j.eneco.2010.04.006

Armey LE, Lipow J, Webb NJ (2014) The impact of electronic financial payments on crime. Inf Econ Policy 29:46-57. doi: 10.1016/j.infoecopol.2014.10.002

Cevik El, Dibooglu S, Kenc T (2016) Financial stress and economic activity in some emerging Asian economies. Res Int Bus Financ 36:127-139. doi:10.1016/j.ribaf.2015.09.017

Conti M (2014) The introduction of the Euro and economic growth: some panel data evidence. J Appl Econ 17 199-211. doi:10.1016/S1514-0326(14)60009-X

European Central Bank (2014) Card payments in europe - a renewed focus on SEPA for cards

Ezuwore-Obodoekwe CN, Eyisi AS, Emengini SE, Chukwubuzo AF (2014) A critical analysis of cashless banking policy in Nigeria. IOSR J Bus Manag 16:30-42. doi:10.9790/487X-16553042

Fox KH (1986) Another step toward the cashless society? the 1978 federal electronic fund

Hasan I, De RT, Schmiedel H (2012) Retail payments and economic growth, Bank Finland Research., pp 1-37

Kao C (1999) Spurious regression and residual-based tests for cointegration in panel data. J Econom 90:1-44. doi:10.1016/S0304-4076(98)00023-2.

Inagaki K (2010) Income inequality and the suicide rate in Japan: evidence from cointegration and LA-VAR. J Appl Econ 13:113-133. doi:10.1016/S1514-0326(10)60006-2

Levin A, Lin CF, Chu CSJ (2002) Unit root tests in panel data: asymptotic and finite-sample properties. J Econom 108:1-24. doi:10.1016/S0304-4076(01)00098-7

Liao W, Handa J (2010) Is the modern economy heading toward a cashless and checkless one ? evidence from the payments system in Canada. IUP J Bank Manag 9:48-71 
Liddle B (2012) The importance of energy quality in energy intensive manufacturing: evidence from panel cointegration and panel FMOLS. Energy Econ 34:1819-1825. doi:10.1016/j.eneco.2012.07.013

Maddala GS, Wu S (1999) A comparative study of unit root tests with panel data and a new simple test. Oxf Bull Econ Stat 61:631-652. doi:10.1111/1468-0084.0610s1631

McCoskey SK, Selden TM (1998) Health care expenditures and GDP: panel data unit root test results. J Health Econ 17: 369-376. doi:10.1016/50167-6296(97)00040-4

Mieseigha EG, Ogbodo UK (2013) An empirical analysis of the benefits of cashless economy on Nigeria's economic development. J Financ Account 4:11-16

Noordin N, Zakaria Z, Mohamed Sawal MZH et al (2012) Bankruptcy among young executives in Malaysia. Intrern Conf Econ Mark Manag 28:132-136

Oyewole OS, El-Maude JG, Abba M, Onuh ME (2013) Electronic payment system and economic growth : a review of transition to cashless economy in Nigeria. Int J Sci Eng Technol 2:913-918

Park J (2012) Corruption, soundness of the banking sector, and economic growth: a cross-country study. J Int Money Financ 31:907-929. doi:10.1016/j.jimonfin.2011.07.007

Paul A, Friday O (2012) Nigeria's cashless economy : the imperatives. Int J Manag Bus Stud 2:31-36

Pedroni P (1999) Critical values for cointegration tests in heterogeneous panels with multiple regressors. Oxf Bull Econ Stat 61:653-670. doi:10.1111/1468-0084.0610s1653

Rogers EM (1995) Diffusion of innovations, Fourth Edi. The Free Press, New York.

Slesman L, Baharumshah AZ, Ra'ees W (2015) Institutional infrastructure and economic growth in member countries of the Organization of Islamic Cooperation (OIC). Econ Model 51:214-226. doi:10.1016/j.econmod.2015.08.008

Wang S, Li Q, Fang C, Zhou C (2016) The relationship between economic growth, energy consumption, and CO2 emissions: Empirical evidence from China. Sci Total Environ 542:360-371. doi:10.1016/j.scitotenv.2015.10.027

Zandi M, Singh V, Irving J (2013) The impact of inequality on economic growth on economic growth, Moody's anal., pp 1-16

\section{Submit your manuscript to a SpringerOpen ${ }^{\circ}$ journal and benefit from:}

- Convenient online submission

Rigorous peer review

- Immediate publication on acceptance

- Open access: articles freely available online

- High visibility within the field

- Retaining the copyright to your article

Submit your next manuscript at $\boldsymbol{\sim}$ springeropen.com 